\title{
Analysis of spirometry results in hospitalized patients aged over 65 years
}

\author{
This article was published in the following Dove Press journal: \\ Clinical Interventions in Aging \\ 29 June 2015 \\ Number of times this article has been viewed
}

\section{Izabela Wróblewska' \\ Piotr Oleśniewicz ${ }^{2}$ \\ Donata Kurpas ${ }^{3}$ \\ Mariusz Sołtysik ${ }^{2}$ \\ Jerzy Błaszczuk ${ }^{4}$}

'Faculty of Health Science, Wroclaw Medical University, ${ }^{2}$ Institute of

Tourism and Recreation, University School of Physical Education in Wroclaw, ${ }^{3}$ Department of Family Medicine, ${ }^{4}$ Faculty of Postgraduate Medical Training, Wroclaw Medical University, Wrocław, Lower Silesia, Poland
Correspondence: Izabela Wróblewska Faculty of Health Science, Wroclaw Medical University, ul Kazimierza Bartla 5, Wrocław 50996, Lower Silesia, Poland $\mathrm{Tel}+48$ 7| 784 I839

Fax +487173459324

Email iz.wroblewska@gmail.com
Introduction and objective: The growing population of the elderly, as well as the occurrence of coexisting diseases and polypharmacy, is the reason why diseases of patients aged $\geq 65$ years belong to the major issues of the contemporary medicine. Among the most frequent diseases of the elderly, there are respiratory system diseases. They are difficult to diagnose because of the patient group specificity, which is the reason for increased mortality among seniors, caused by underdiagnosis. The study objective was to assess the factors influencing spirometry results in hospitalized patients aged $\geq 65$ years with respiratory system disorders.

Material and methods: In the research, 217 (100\%) patients aged $\geq 65$ years who underwent spirometry at the Regional Medical Center of the Jelenia Góra Valley Hospital in Poland were analyzed. In the statistical analysis, the STATISTICA 9.1 program, the $t$-test, the Shapiro-Wilk test, the ANOVA test, and the Scheffé's test were applied.

Results: The majority of the patients $(59.4 \%)$ were treated in the hospital. The most frequent diagnosis was malignant neoplasm (18\%). The study showed a statistically significant dependence between the forced vital capacity (FVC), forced expiratory volume in 1 second $\left(\mathrm{FEV}_{1}\right)$, and $\mathrm{FEV}_{1} / \mathrm{FVC}$ parameters and the time of hospitalization, as well as between the FVC and $\mathrm{FEV}_{1}$ parameters and the age of patients. The FVC parameter values turned out to be dependent on the main diagnosis. Highest results were noted in patients with the diagnosis of sleep apnea or benign neoplasm. A low FVC index can reflect restrictive ventilation defects, which was supported by the performed analyses. Highest $\mathrm{FEV}_{1} / \mathrm{FVC}$ values were observed in nonsmokers, which confirms the influence of nicotine addiction on the incidence of respiratory system diseases.

Conclusion: The respondents' sex and the established diagnosis statistically significantly influenced the FVC index result, and the diet influenced the $\mathrm{FEV}_{1} / \mathrm{FVC}$ parameter result.

Keywords: the elderly, spirometry, respiratory system diseases

\section{Introduction}

The constantly increasing number of people aged $\geq 65$ years implies the necessity to intensify and improve the medical care offered to this group of patients. The multiple concomitant diseases and related polypharmacy in the elderly are the reasons why the reliable diagnostic process is difficult and demands a holistic approach. The assessment of the clinical condition of an elderly patient should include the interactions among the specific disease entities and the burden resulting from the superimposing pathogens. ${ }^{1,2}$

Respiratory system diseases occurring in people aged $\geq 65$ years constitute a complex problem; the cases of paroxysmal or chronic dyspnea should be diagnosed within the basic diagnostic process and should not be treated only as an iatrogenic complication. 
Establishing proper diagnosis is also significant because of the six-fold increased mortality occurring in seniors with reference to incorrect diagnosis or underdiagnosis. ${ }^{3}$ Moreover, the cognitive function disorders that can be present in the elderly considerably influence the accurate examining process. $^{4}$

According to international studies, the most frequent diseases affecting the respiratory system that occur in the elderly are neoplasms, chronic respiratory failure, lung and bronchial inflammatory conditions, and bronchial asthma, which is divided into late- or very late-onset asthma and late- or early-onset old-age asthma (the disease starts before the elderly age and is characterized by a long-term course, reaching elderly age). ${ }^{5}$

Because of the frequency of occurrence of respiratory system diseases in seniors, spirometry should be performed within the basic diagnostic process. It is a useful diagnostic tool, allowing to assess and monitor the lung function and to evaluate the efficiency of spasmolytic drugs. It is a valuable tool for disease progress follow-up. One should take into account that the examination results depend on the condition, structure, and reactivity of the respiratory tract, concomitant diseases, and the possibility to perform the examination properly.,

The diagnostic process in elderly patients is additionally hampered by the occurrence of chronic obstructive pulmonary disease (COPD) as well as decreased lung recoil pressure, chest compliance, and respiratory muscle force; it is also complicated in smokers. ${ }^{7}$

\section{Objective}

The study objective was to assess the factors influencing spirometry results in hospitalized patients aged $\geq 65$ years with respiratory system disorders.

\section{Material and methods}

Medical documentation of patients treated at the Regional Medical Center of the Jelenia Góra Valley Hospital in Poland between January and December 2012 was analyzed. The analysis referred to the age, sex, place of residence, main diagnosis, place of treatment (inpatients vs outpatients), recommended diet, nicotine dependence, spirometry results, and the time of hospital stay.

Statistical analysis was performed with the STATISTICA 9.1 program. For the measurable variables, arithmetic means, standard deviations, and ranges of variation were calculated. For qualitative variables, their frequency was calculated. The quantitative variables were examined by the Shapiro-Wilk test to determine the distribution type. To compare the results, the $t$-test, the one-way analysis of variance (ANOVA) test, and the post hoc test (Scheffé's test) were applied. For all comparisons, the level of $\alpha=0.05$ was assumed. The obtained $P$-values were rounded. Additionally, the dependence between chosen variables was determined with the use of the Pearson correlation test $(\alpha=0.05)$.

The authors obtained the consent of the Bioethical Committee of the Wroclaw Medical University No KB 608/2011 and of the Director of the Jelenia Góra hospital.

\section{Group characteristics}

In the research, the medical documentation of $217(100 \%)$ patients aged $\geq 65$ years was analyzed; $54.8 \%$ of the patients (119) were men and $45.2 \%$ of the patients (98) were women. The patients' age ranged from 65 years to 89 years $(\bar{x}=70.1 \pm 5.5$ years $)$. The majority of participants $(70 \% ; 160)$ lived in cities. Most patients were on a normal diet $(70.5 \%$; 153), $11.1 \%$ (24) were on an easily digestible diet, $17.1 \%$ (37) were on a diabetic diet, and $1.3 \%$ (3) were on a liver disease diet. Patients received diet based on other medical conditions. Regardless the diet regimen, they received 2,500 calories a day. There were no cases of malnutrition observed during the study. In the studied population, $53.9 \%$ (117) declared being nonsmokers, 35.5\% (77) were habitual smokers, $9.7 \%$ (21) were former smokers, and $0.9 \%$ (2) were passive smokers.

\section{Results}

The majority of patients $(59.4 \% ; 129)$ stayed in the hospital; the rest $(40.6 \% ; 88)$ were treated in the outpatient pulmonology clinic.

The most frequently established diagnoses were as follows: malignant neoplasm $(18 \% ; 39)$, other specified respiratory system diseases $(17.5 \%$; 38) (including interstitial lung diseases, COPD, lung tissue diseases with fibrosis, lung abscess, hyperventilation, pyothorax, and hemoptysis), unspecified respiratory system diseases $(14.7 \% ; 32)$, bronchial asthma $(12.4 \% ; 27)$, sleep apnea $(7.4 \% ; 16)$, benign neoplasm or chronic respiratory failure $(6.5 \%$ each; 14 each), bronchiectasis or acute respiratory failure $(4.6 \%$ each; 10 each), bronchitis or sarcoidosis ( $2.8 \%$ each; 6 each), pneumonia $(1.4 \% ; 3)$, and pneumoconiosis $(0.9 \% ; 2)$.

The patients' hospitalization time ranged from 2 days to 25 days ( $\bar{x}=5.4 \pm 3.5$ days); in women (98), it ranged from 2 days to 19 days ( $\bar{x}=5.6 \pm 3.3$ days), and in men (119), it ranged from 2 days to 25 days ( $\bar{x}=5.2 \pm 3.6$ days). There is no statistically significant difference between these results $(P>0.05)$. 
Table I Results for the FEV,/FVC parameter (\%) depending on nicotine addiction

\begin{tabular}{lllllllll}
\hline \multirow{2}{*}{ Nicotine addiction } & \multicolumn{3}{l}{ FEV $/$ FVC (\%) } & \multicolumn{3}{c}{ P-value Post hoc } \\
\cline { 2 - 6 } & N & \multicolumn{3}{c}{ Mean } & SD & Min & Max & \\
\hline Nonsmokers & 117 & 75 & 14 & 37 & 100 & 0.003 & $1: 2-P=0.356$ \\
Former smokers & 21 & 70 & 12 & 44 & 96 & & $1: 3-P=0.004$ \\
Nicotine addicts & 77 & 68 & 16 & 17 & 100 & & $2: 3-P=0.828$ \\
\hline
\end{tabular}

Abbreviations: $\mathrm{FEV}_{1}$, forced expiratory volume in I second; FVC, forced vita capacity; SD, standard deviation.

The results concerning the forced vital capacity (FVC) and forced expiratory volume in 1 second $\left(\mathrm{FEV}_{1}\right)$ parameters differed between men and women $(\bar{x}=2.6 \pm 1.1, \bar{x}=3.4 \pm 1.2$, $P<0.001$ and $\bar{x}=1.9 \pm 0.9, \bar{x}=24 \pm 1.1, P<0.001$, respectively). The results of the $\mathrm{FEV}_{1} / \mathrm{FVC}$ parameter (in \%) obtained for both sexes were similar and remained within the range of $37 \%-100 \%(\bar{x}=72 \pm 15)$. The comparison shows no statistically significant difference between them $(P>0.05)$.

There was no relationship observed between the place of residence and the results for the FVC $(P>0.05)$, FEV $(P>0.05)$, and $\mathrm{FEV}_{1} / \mathrm{FVC}(\%)(P>0.05)$ parameters, as well as the diet applied $(P>0.05)$. The diet did not influence the FVC $(P>0.05)$ or $\mathrm{FEV}_{1}(P>0.05)$ parameter results; however, a statistically significant dependence was proved for the $\mathrm{FEV}_{1} / \mathrm{FVC}$ parameter (\%).

The study showed no statistically significant dependence between the results concerning hospitalization time $(P>0.05)$ and the FVC $(P>0.05)$ and $\mathrm{FEV}_{1}(P>0.05)$ parameters among patients who were nonsmokers, former smokers, or nicotine addicts. In turn, statistically significant differences were noted among the results $(P=0.0034)$ for the $\mathrm{FEV}_{1} / \mathrm{FVC}$ parameter (\%) in particular groups (Table 1).

There was also a statistically significant correlation between the influence of the specificity of particular hospital wards and the outpatient pulmonology clinic running the treatment on the results of FVC $(P>0.05), \mathrm{FEV}_{1}(P>0.05)$, or $\mathrm{FEV}_{1} / \mathrm{FVC}(P>0.05)$ parameters. However, hospitalization time proved to be dependent on the main diagnosis $(P<0.001)$ (Table 2).

The study showed that the range of the FVC parameter values among patients with a malignant neoplasm was $1.0-4.5(\bar{x}=2.8 \pm 0.9)$, with other specified respiratory system diseases was $1.7-60(\bar{x}=3.2 \pm 1.0)$, with sleep apnea was 1.8-5.6 ( $\bar{x}=3.6 \pm 1.1)$, with bronchial asthma was 1.6-5.2 $(\bar{x}=3.3 \pm 1.2)$, with unspecified respiratory system diseases was $0.8-6.6(\bar{x}=2.8 \pm 1.4)$, with benign neoplasms was $1.1-5.3$ $(\bar{x}=3.6 \pm 1.2)$, with bronchiectasis was $0.8-4.1(\bar{x}=2.7 \pm 0.9)$, with acute respiratory failure was $0.9-3.7(\bar{x}=2.1 \pm 1.0)$, and with chronic respiratory failure was $0.7-4.7(\bar{x}=2.3 \pm 1.3)$. Statistically significant differences among the results were observed $(P=0.0011)$.

The range of the $\mathrm{FEV}_{1}$ parameter values among patients with a malignant neoplasm was $0.9-3.2(\bar{x}=2.0 \pm 0.7)$, with other specified respiratory system diseases was $0.9-4.8$ $(\bar{x}=2.3 \pm 1.0)$, with sleep apnea was $1.5-4.6(\bar{x}=2.9 \pm 0.8)$, with bronchial asthma was $0.6-4.2(\bar{x}=2.4 \pm 1.0)$, with unspecified respiratory system diseases was $0.8-6.2(\bar{x}=2.2 \pm 1.2)$, with benign neoplasms was $0.7-4.7(\bar{x}=2.8 \pm 1.1)$, with bronchiectasis was $0.8-3.3(\bar{x}=2.1 \pm 0.7)$, with acute respiratory failure was $0.7-1.8(\bar{x}=1.2 \pm 0.4)$, and with chronic respiratory failure was $0.6-3.3(\bar{x}=1.3 \pm 0.8)$. Statistically significant differences were seen among the obtained results $(P<0.001)$.

Also, the results for the $\mathrm{FEV}_{1} / \mathrm{FVC}$ parameter (\%) were analyzed. The range of the $\mathrm{FEV}_{1} / \mathrm{FVC}$ parameter values (\%) among patients with the main diagnosis of a malignant neoplasm was $50 \%-100 \%(\bar{x}=72.0 \pm 11.8)$, with other specified respiratory system diseases was $17 \%-96 \%(\bar{x}=67.3 \pm 16.1)$,

Table 2 Number of hospitalization days depending on the diagnosis

\begin{tabular}{|c|c|c|c|c|c|c|}
\hline \multirow[t]{2}{*}{ Main diagnosis } & \multicolumn{5}{|c|}{ Number of hospitalization days } & \multirow{2}{*}{$\begin{array}{l}\text { P-value (one-way ANOVA } \\
\text { Kruskal-Wallis test) }\end{array}$} \\
\hline & $\mathbf{N}$ & Mean & SD & Min & Max & \\
\hline Malignant neoplasm & 39 & 5.6 & 3.2 & 2.0 & 15.0 & $<0.0001$ \\
\hline $\begin{array}{l}\text { Other specified respiratory } \\
\text { system diseases }\end{array}$ & 38 & 5.4 & 2.6 & 2.0 & 12.0 & \\
\hline Sleep apnea & 16 & 2.6 & 0.6 & 2.0 & 4.0 & \\
\hline Bronchial asthma & 27 & 4.4 & 3.7 & 2.0 & 19.0 & \\
\hline $\begin{array}{l}\text { Unspecified respiratory } \\
\text { system diseases }\end{array}$ & 32 & 5.0 & 2.9 & 2.0 & 12.0 & \\
\hline Benign neoplasm & 14 & 4.0 & 2.8 & 2.0 & 12.0 & \\
\hline Bronchiectasis & 10 & 4.6 & 2.1 & 2.0 & 8.0 & \\
\hline Acute respiratory failure & 10 & 7.6 & 3.6 & 3.0 & 16.0 & \\
\hline Chronic respiratory failure & 14 & 8.9 & 3.3 & 3.0 & 14.0 & \\
\hline
\end{tabular}

Abbreviations: ANOVA, analysis of variance; SD, standard deviation. 
with sleep apnea was $71 \%-91 \%(\bar{x}=80.6 \pm 13.7)$, with bronchial asthma was $41 \%-94 \%(\bar{x}=72.8 \pm 13.7)$, with unspecified respiratory system diseases was $45 \%-100 \%(\bar{x}=77.3 \pm 16.2)$, with benign neoplasms was $54 \%-87 \%(\bar{x}=75.8 \pm 9.8)$, with bronchiectasis was $51 \%-100 \%(\bar{x}=80.5 \pm 13.9)$, with acute respiratory failure was $42 \%-94 \%(\bar{x}=65.8 \pm 19.5)$, and with chronic respiratory failure was $37 \%-86 \%(\bar{x}=60.6 \pm 15.5)$. Statistically significant differences were observed among the results $(P<0.001)$.

Within the research, the correlations were also analyzed between the patients' age, hospitalization time, and the FVC parameter results. Significant correlations were observed between the hospitalization time and the values of the FVC $(r=0.39, P<0.001), \mathrm{FEV}_{1}(r=0.44, P<0.001)$, and $\mathrm{FEV}_{1} /$ FVC $(\%)(r=0.32, P<0.001)$ parameters, as well as between the FVC $(r=-0.21, P=0.002)$ and $\mathrm{FEV}_{1}$ parameters and the patients' age $(r=-0.18, P=0.009)$ and the number of hospitalization days $(r=-0.16, P=0.022)$.

No statistically significant correlation was observed between the FVC parameter value and $\mathrm{BMI}(r=0.04, P=0.583)$, $\mathrm{FEV}_{1}$ parameter value and $\mathrm{BMI}(r=0.07, P=0.332)$, and $\mathrm{FEV}_{1} /$ FVC parameter value $(\%)$ and BMI $(r=0.04, P=0.581)$.

\section{Discussion}

In elderly patients, lung elasticity impairment occurs, resulting in peripheral respiratory tract instability, premature obturation, and gas exchange disorders caused by improper balance between ventilation and perfusion. Because of the worsening anatomical conditions, cardiovascular system disorders, psychophysical impairment, and motor system atrophy, the course of respiratory system diseases in seniors usually turns out more severe than in younger patients. Immunological reactions are also of some importance; they become considerably milder with the passage of time, which results in milder disease attacks, with rarer and longer remissions. ${ }^{8}$

Respiratory system diseases in the elderly are a complex medical problem. They are difficult to diagnose owing to the presence of concomitant diseases. A careful diagnostic process performed in patients aged $\geq 65$ years should contribute to increased detectability of the diseases under discussion, and therefore to improved therapeutic effects. What is important is a positive dependence among the degrees of managing each of the chronic diseases, as a better control of each of them results in a milder course of the others. ${ }^{4}$

The majority of the patients in the study were treated in the hospital. This is, however, a situation of little comfort for seniors because hospitalization constitutes a serious factor increasing stress and the risk of complications. ${ }^{9-11}$
The authors also analyzed the hospitalization time, which was strongly diverse (2-25 days), and additionally, it was longer in the case of men. The time of hospital stay depended on the general condition of the patients, their disease, and the level of self-care. In patients who were not self-reliant, the hospitalization period was usually longer, allowing to counteract the lack of control over the possible occurrence of adverse effects of the treatment. ${ }^{12}$

In accordance with the recommendations of the Polish Phtysiopneumonological Society, ${ }^{13}$ spirometry was performed in all patients. This is an examination of special significance in the elderly who present with a weak perception of respiratory system disease symptoms. In this case, spirometry should be performed several times: during the entrance visit, as part of controlling the patient's condition, after treatment implementation and obtaining symptoms improvement, in the situation of worsening the patient's condition or the progress of the disease, and additionally, as a yearly control. ${ }^{14}$

It is a difficult task to properly perform spirometry; the examination requires efficient cooperation between the patient and the technician to fulfill the demands of repeatability and correctness. When the patients' cognitive competence is impaired, performing spirometry becomes especially troublesome because of the existing dementia or disability. Moreover, the examination is also a burden for the patient, as the subsequent intense respiratory manoeuvers can be compared to the exercise test. ${ }^{15}$ Thus, cardiac arrhythmias can occur in the course of spirometry. Therefore, for safety reasons, patients should be examined in a sitting position, and the history of myocardial infarction should constitute an absolute contraindication to performing spirometry. ${ }^{16}$

The results obtained for the FVC parameter differed between men and women. Among women, there was a bigger result range observed and the values were higher than in men. Moreover, a statistically significant dependence was noted between the FVC parameter values and the patients' age: the results were lower in the so-called older elderly than in the younger elderly. These outcomes reflect the study results obtained by Falaschetti et al who found out that the physiological value of the FVC index differed between men and women and decreased with age. One should not therefore arbitrarily assume a stable value for the index's lower norm limit, as this could result in false-positive outcomes. ${ }^{17,18}$

Statistically significant differences were also observed between the $\mathrm{FEV}_{1}$ parameter results in both sexes, as well as between the values of this parameter and the patients' age. The results for the $\mathrm{FEV}_{1}$ parameter in women were higher than in men, which is consistent with the outcomes obtained by 
Sharma and Goodwin. The researchers observed that the FEV parameter values gradually decreased with age and were additionally dependent on individual factors, including sex. ${ }^{19}$

The study also included the $\mathrm{FEV}_{1} / \mathrm{FVC}$ comparison analysis. The parameter turns out to be dependent on the patient's sex, height, and body mass. It decreases when a disease occurs. ${ }^{13}$ Among the respondents, the $\mathrm{FEV}_{1} / \mathrm{FVC}$ index remained within the range of $37 \%-100 \%$. Low values depend on the main diagnoses established in patients; if the $\mathrm{FEV}_{1}$ value decreases, the $\mathrm{FEV}_{1} / \mathrm{FVC}$ index becomes smaller. ${ }^{20}$ Lowered values of the index point at an obstructive ventilation defect - when an obstruction for the air flow in the respiratory tract occurs, within the first second of the exhalation, the patient is not able to exhale an appropriate quantity of air from the lungs in relation to the total amount of air in the lungs.

The relation of $\mathrm{FEV}_{1}$ to $\mathrm{FVC}$ is a factor that supports establishing the diagnosis. According to the European Respiratory Society criteria, COPD should be diagnosed with $\mathrm{FEV}_{1}(\%)<88 \%$ of the predicted value in men or $<89 \%$ in women. ${ }^{21}$ In a restrictive lung disease, $\mathrm{FEV}_{1}$ and $\mathrm{FVC}$ can also be lowered owing to fibrosis or some other lung pathology.

There was no relationship observed between the place of residence and the frequency of respiratory tract diseases, which remains in contrast to other literature reports within this issue. ${ }^{22}$ This seems to be caused by the place of performing the research (lack of big urban agglomerations and respondents coming from small towns and rural areas).

The performed analyses showed that the patients' diet did not influence the values of the $\mathrm{FVC}$ and $\mathrm{FEV}_{1}$ parameters. This confirms literature reports maintaining that the relationship between food allergens and, for instance, asthma is difficult to prove. An atopic patient presenting with skin lesions and digestive system abnormalities can suffer from asthma of a different origin. Although a significant percentage of allergic reactions to food is suggested in younger patients, there is no practical evidence for the phenomenon in the elderly. ${ }^{8}$ However, the research revealed a statistically significant difference in this issue concerning the value of the $\mathrm{FEV}_{1} / \mathrm{FVC}$ parameter.

No statistically significant correlation was observed between the hospitalization time and the values of the FVC and $\mathrm{FEV}_{1}$ parameters among nonsmokers, former smokers, and present smokers. In turn, statistically significant differences were noted between the results for the $\mathrm{FEV}_{1} / \mathrm{FVC}$ parameter obtained in the mentioned groups. Highest values were observed in nonsmokers, which confirms the influence of nicotine addiction on the incidence of respiratory system diseases. ${ }^{23}$

Within the analysis, particular spirometry results were confronted with the established diagnoses. The FVC parameter values turned out to be dependent on the main diagnosis. Highest results were noted in patients with the diagnosis of sleep apnea or benign neoplasm. A low FVC index can reflect restrictive ventilation defects, ${ }^{24}$ which was supported by the performed analyses. The widest range of values was observed in patients with unspecified respiratory system diseases and with chronic respiratory failure. The structure of the $\mathrm{FEV}_{1}$ parameter results was similar.

In turn, the $\mathrm{FEV}_{1} / \mathrm{FVC}$ index turned out highest among patients with the diagnosis of malignant neoplasm, sleep apnea, and bronchiectasis. The widest range of values was observed in patients with acute respiratory failure, specified and unspecified respiratory system diseases, and chronic respiratory failure.

Here, one should definitely consider the progression of the disease process as well as the level of its control by the patients themselves and by the medical care professionals. Disciplined patients receiving specialist treatment show smaller ranges of spirometry results than those who do not follow medical advice. This is reflected in the prognosis, which is uncertain in the elderly and depends on the course of diseases. ${ }^{8}$

When analyzing the time of hospital stays, the authors observed that longer hospitalization positively influenced the results of the $\mathrm{FVC}, \mathrm{FEV}_{1}$, and $\mathrm{FEV}_{1} / \mathrm{FVC}$ parameters. This means that during hospital stays, patients receive specialist care, which allows to improve both the examination results and the patients' general feeling. Treatment and nursing in a medical center implies the possibility to implement a wider spectrum of procedures and to precisely monitor their results. $^{25}$

\section{Conclusion}

1. The patients' sex influenced the values of spirometry parameters: women obtained better results.

2. The patients' age influenced the values of spirometry parameters: the older the patients, the worse the results, pointing at the presence of a ventilation defect.

3. The $\mathrm{FEV}_{1} / \mathrm{FVC}$ index turned out to be a factor that supported establishing the diagnosis.

4. The place of residence and the diet remained with no impact on spirometry results, in contrary to nicotine addiction.

5. A longer hospitalization time positively influenced spirometry results.

\section{Disclosure}

The authors report no conflicts of interest in this work. 


\section{References}

1. Weel van C, Schellevis FG. Comorbidity and guidelines: conflicting interests. Lancet. 2006;367(9510):550-551.

2. Petty TL, Seebass JS, Broczek K. Choroby płuc w podeszłym wieku: rozpoznawanie, zapobieganie i leczenie [Pulmonary diseases in the elderly: diagnosis, prophylaxis, and treatment]. Med Dypl. 2008;11: 60-66. Polish.

3. Enright PL, McClelland RL, Newman AB, Gottlieb DJ, Lebowitz MD. Underdiagnosis and undertreatment of asthma in the elderly. Chest. 1999;116(3):603-613.

4. Panaszek B, editor. Astma oskrzelowa w podeszłym wieku [Bronchial asthma in the elderly]. Poznań: Termedia; 2011:28-51. Polish.

5. Lee S, Lee H, Lee S, et al. Clinical characteristics of early- and lateonset elderly asthma. J Allergy Clin Immunol. 2009;123(2):220.

6. Bellia V, Pistelli R, Catalano F, et al. Quality control of spirometry in the elderly. The SA.R.A. study. SAlute Respiration nell'Anziano = Respiratory Health in the Elderly. Am J Respir Crit Care Med. 2000;161: 1094-1100.

7. Moreira S, Lopes A, Cadarso F, Coutinho A, Leitão C, Dias F. Communityacquired pneumonia in a central hospital - comparison between a group of elderly and a non-elderly patients. Rev Port Pneumol. 2003; 9:7-8.

8. Droszcz W. Astma [Asthma]. Warsaw: PZWL; 2007:43-63. Polish.

9. Wróblewska I, Steciwko A. Różnice i podobieństwa w sprawowanej opiece nad osobami starszymi przebywającymi w ośrodkach opieki w Polsce i we Francji [Differences and similarities in the care provided to the elderly residents of care centers in Poland and France]. Gerontol Pol. 2010;20(1):22-27. Polish.

10. Muszalik M, Kędziora-Kornatowska K, Ciosek A. Problemy związane z adaptacją oraz oczekiwania hospitalizowanych osób w starszym wieku [Problems associated with adaptation and the expectations of hospitalized elderly patients]. Gerontol Pol. 2008;16(1):41-46. Polish.

11. Halicka M, Jermolaj A. Hospitalizacja jako czynnik stresujący pacjentów w starszym wieku. [Hospitalization as a stressful factor in elderly patients]. In: Krajewska-Kułak E, Sierakowska M, Lewko J, Łukaszuk C, editors. Pacjent podmiotem troski zespolu terapeutycznego [The Patient as the Subject of the Therapeutic Team Care]. Bialystok: Medical University Publishers; 2005:211-220. Polish.

12. Basińska A. Leczenie uzależnienia od benzodiazepin u osób w wieku podeszłym [Treating benzodiazepine dependence in elderly people]. Post Nauk Med. 2011;23(8):644-648. Polish.
13. Śliwiński P, Górecka D, Jassem E, Pierzchała W. Zalecenia Polskiego Towarzystwa Ftyzjopneumonologicznego [Recommendations of the Polish Phtysiopneumonological Society]. Pneumon Alergol Pol. 2012; 80:220-254. Polish

14. Bochenek G, Doniec Z, Kryj-Radziszewska E. Astma oskrzelowa [Bronchial Asthma]. Warsaw: PZWL; 2011:56-98. Polish.

15. Dor-Wojnarowska A, Liebhart J. Badanie spirometryczne osób starszych. [Spirometry in the elderly]. In: Panaszek B, editor. Astma oskrzelowa w podeszlym wieku [Bronchial Asthma in the Elderly]. Poznań: Termedia; 2011:9-75. Polish.

16. Araújo CG, Vianna LC. How often does spirometry testing induce cardiac arrhythmias? Prim Care Respir J. 2009;18(3):185-188.

17. Silverman RA, Flaster E, Enright PL, Simonson SG. FEV ${ }_{1}$ performance among patients with acute asthma: results from a multicenter clinical trial. Chest. 2007;131(1):164-171.

18. Falaschetti E, Laiho J, Primatesta P, Purdon S. Prediction equations for normal and low lung function from the Health Survey for England. Eur Respir J. 2004;23(3):456-463.

19. Sharma G, Goodwin J. Effect of aging on respiratory system physiology and immunology. Clin Interv Aging. 2006;1(3):253-260.

20. Swanney MP, Rúppel G, Enright PL, et al. Using the lower limit of normal for the $\mathrm{FEV}_{1} / \mathrm{FVC}$ ratio reduces the misclassification of airway obstruction. Thorax. 2008;63(12):1046-1051.

21. Nathell L, Nathell M, Malmberg P, Larsson K. COPD diagnosis related to different guidelines and spirometry techniques. Respir Res. 2007;8(1):89.

22. Sozańska B, McNeill S, Kajerowicz M. Atopy in Rural Poland: Protection of all Ages. San Diego: ATS; 2005:67-85.

23. Gortmaker SL, Walker DK, Jacobs FH, Ruch-Ross H. Parental smoking and the risk of childhood asthma. Am J Public Health. 1982;72(6): 574-579.

24. Grabska-Chrząstkowska J, Tomalak W. Zastosowanie sieci neuronowych w analizie wyników badania spirometrycznego. [Neural network application in the analysis of spirometry results]. In: Tadeusiewicz R, Korbicz W, Rutkowski L, Duch W, editors. Sieci neuronowe winżynierii biomedycznej [Neural Networks in Bioengineering]. Warsaw: Exit; 2013:335-352. Polish.

25. Metersky ML, Sweeney TA, Getzow MB, Siddiqui F, Nsa W, Bratzler DW. Antibiotic timing and diagnostic uncertainty in Medicare patients with pneumonia: is it reasonable to expect all patients to receive antibiotics within 4 hours? Chest. 2006;130(1):16-21.
Clinical Interventions in Aging

\section{Publish your work in this journal}

Clinical Interventions in Aging is an international, peer-reviewed journal focusing on evidence-based reports on the value or lack thereof of treatments intended to prevent or delay the onset of maladaptive correlates of aging in human beings. This journal is indexed on PubMed Central, MedLine,

\section{Dovepress}

CAS, Scopus and the Elsevier Bibliographic databases. The manuscript management system is completely online and includes a very quick and fair peer-review system, which is all easy to use. Visit http://www.dovepress. com/testimonials.php to read real quotes from published authors. 